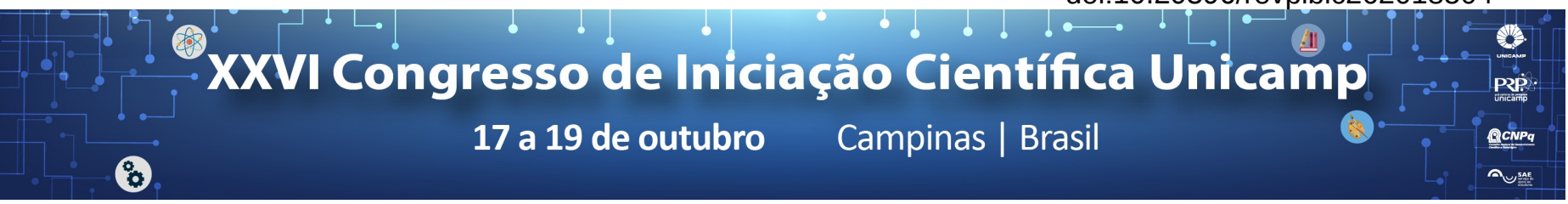

\title{
Alterações mineralógicas em Plintossolos associadas à inundação prolongada
}

\author{
Gabriela E. Pereira*, Alfredo B. De-Campos
}

\begin{abstract}
Resumo
A formação de Plintossolos ocorre em regiões úmidas ou sub-úmidas. Alterações nas condições de hidromorfia desses solos, causadas entre diversos fatores, por inundação natural ou decorrente de irrigação agrícola, podem potencialmente levar a mudanças na geoquímica e na mineralogia dos Plintossolos. Esta pesquisa objetivou determinar a mineralogia de Plintossolos que se encontram sob efeito de inundação prolongada e compará-la com a mineralogia desses solos sob regime hídrico natural. A pesquisa envolveu preparação de amostras de solo e posterior analise por difratometria de raios- $X$ para determinação da mineralogia. A pesquisa foi desenvolvida com amostras de Plintossolos coletadas em área do projeto de irrigação Luis Alves do Araguaia, Estado de Goiás. Os resultados indicaram mudanças na mineralogia e neoformação de minerais em consequência da inundação prolongada.
\end{abstract}

\section{Palavras-chave:}

Plintossolos, mineralogia, inundação.

\section{Introdução}

Plintossolos tem sua gênese associada a períodos com excesso de água sendo caracterizados pela presença de horizonte plintico ou litoplintico (EMBRAPA, 2006). A sazonalidade hidrológica influencia na formação dos Plintossolos, uma vez que a gênese e evolução das plintitas estão relacionadas com a dissolução e neoformação de minerais. Deste modo, mudanças no regime hidrológico causadas por condições de inundação prolongada podem potencialmente instabilizar geoquímica e mineralogicamente os constituintes destes solos e alterar sua mineralogia.

A presente pesquisa objetivou determinar a mineralogia de Plintossolos que se encontram sob efeito de inundação prolongada e compará-la com a mineralogia desses solos sob regime hídrico sazonal natural através da análise por difratometria de raios- $X$ (DRX). A hipótese testada foi de que a inundação prolongada modifica a mineralogia de Plintossolos.

Amostras do horizonte $\mathrm{Bf} 2$ de três trincheiras (TR2 sob vegetação natural; TR3 e TR4 sob inundação) foram preparadas para análise por DRX para o pó total e fração argila, segundo Camargo ET al. (2009). Os procedimentos envolveram moagem $(0,063 \mathrm{~mm})$ para obtenção do pó total e confecção de lâminas delgadas orientadas da fração argila sem nenhum tratamento (normal), glicoladas e aquecidas. Os resultados das análises por DRX foram interpretados com o auxilio do software X'Pert HighScore Plus.

\section{Resultados e Discussão}

As fases minerais detectadas são apresentadas na tabela 1. A mineralogia do pó total (matriz e plintita) foi semelhante para todas as amostras. Diferenças em mineralogia apareceram na fração argila. Nessa fração foram detectados minerais formados em ambiente com excesso de água para as amostras do horizonte $\mathrm{Bf} 2 \mathrm{em}$ TR3 e TR4, como fengita e vermiculita. Isso indica que a inundação prolongada de Plintossolos modifica sua mineralogia.
Tabela 1. Principais minerais encontrados na análise do pó total da matriz e das plintitas, assim como da fração argila, do horizonte Bf2 das trincheiras TR2, TR3 e TR4.

\begin{tabular}{|c|c|c|c|}
\hline & TR2 & TR3 & TR4 \\
\hline $\begin{array}{c}\text { Pó total } \\
\text { (matriz) }\end{array}$ & $\begin{array}{c}\text { ilita+clorita } \\
\text { quartzo } \\
\text { caulinita }\end{array}$ & $\begin{array}{c}\text { quartzo } \\
\text { caulinita }\end{array}$ & $\begin{array}{c}\text { quartzo } \\
\text { caulinita }\end{array}$ \\
\hline $\begin{array}{c}\text { Pó total } \\
\text { (plintita) }\end{array}$ & $\begin{array}{c}\text { quartzo } \\
\text { hematita } \\
\text { caulinita } \\
\text { goethita }\end{array}$ & $\begin{array}{c}\text { quartzo } \\
\text { caulinita } \\
\text { goethite }\end{array}$ & $\begin{array}{c}\text { quartzo } \\
\text { hematita } \\
\text { caulinita } \\
\text { goethite }\end{array}$ \\
\hline $\begin{array}{c}\text { Fração } \\
\text { argila } \\
\text { orientada }\end{array}$ & $\begin{array}{c}\text { quartzo } \\
\text { hematit, } \\
\text { caulinita } \\
\text { goethita }\end{array}$ & $\begin{array}{c}\text { vermiculita } \\
\text { fengita } \\
\text { caulinita } \\
\text { quartzo }\end{array}$ & $\begin{array}{c}\text { quartzo } \\
\text { caulinita } \\
\text { vermiculita } \\
\text { polimorfo } \\
\text { de biotita }\end{array}$ \\
\hline
\end{tabular}

\section{Conclusão}

Através das analises das amostras de Plintossolos pela difração de raios- $X$ foi possível determinar os principais minerais presentes no horizonte $\mathrm{Bf} 2$ das trincheiras TR2, TR3 e TR4. A presença de fases minerais formadas em consequência da inundação prolongada comprova a hipótese de que a inundação prolongada modifica a mineralogia de Plintossolos.

\section{Agradecimentos}

Os autores agradecem a FAPESP (projeto $n$. 2016/01270-0) e ao CNPq (bolsa produtividade em pesquisa) pelo apoio financeiro e aos professores Drs. Ricardo Perobelli Borba e Fresia Ricardi-Branco do IGUnicamp pelo apoio para obtenção e tratamento dos dados da pesquisa.

CAMARGO, O.A; MONIZ, A.C; JORGE, J.A.; VALADARES, J.M.A.S Métodos de Analise Química, Mineralógica e Física de Solos do Instituto Agronômico de Campinas. Campinas, Instituto Agronômico, 2009. 77 p. (Boletim técnico, 106, Edição revista e atualizada).

EMBRAPA Centro Nacional de Pesquisa de Solos. 2006. Sistema brasileiro de classificação de solos $2^{\mathrm{a}}$ ed. Rio de Janeiro: EMBRAPA SPI. 